\title{
Activity rhythms in some burrowing decapods
}

\author{
R. J. A. AtKinson \& E. NAYLOR \\ Marine Biological Station, University of Liverpool; \\ Port Erin, Isle of Man
}

\begin{abstract}
KURZFASSUNG: Aktivitätsrhythmen bei einigen höhlengrabenden Decapoden. Es wird dargelegt, daß Untersuchungen über rhythmische Erscheinungen mariner Tiere ergänzender In-situ-Beobachtungen bedürfen, um die biologische Bedeutung von Periodizitätsphänomenen möglichst zweifelsfrei interpretieren zu können. Circadiane Rhythmen treten bei höhlengrabenden Decapoden deutlicher hervor, wenn den Versuchstieren künstliche Schlupfwinkel geboten werden, wie durch Aktivitätsregistrierungen an Goneplax rbomboides und Nephrops norvegicus unter zeitgeberfreien Laboratoriumsbedingungen (bei konstantem $\mathrm{Dämmerlicht)} \mathrm{be-}$ wiesen werden konnte. Experimente an Uca pugilator haben ergeben, daß die gezeitenrhythmische Lokomotionsperiodik durch soziale Kontakte beeinflußt wird. Bei größeren Gruppen wurde eine relativ geringere Aktivitätsmenge als bei kleineren Gruppen oder einzeln getesteten Individuen registriert. Die endogene Rhythmik höhlengrabender Decapoden erweist sich als außerordentlich persistent. Es wird erörtert, inwieweit dieser Persistenz eine adaptive Bedeutung zukommt.
\end{abstract}

\section{INTRODUCTION}

Many studies on locomotor thythmicity have been carried out with the experimental animals maintained in unfamiliar or atypical surroundings. Such studies are important in the analysis of external and internal factors controlling rhythmicity but the results of those experiments should be carefully assessed when attempting to interpret their ecological significance. For example, the amphipod Talitrus saltator has recently been shown to exhibit a different pattern of rhythmicity when kept in a perspex box than when provided with sand in which to burrow (BREGAzzI \& NAYLOR 1972). T. saltator kept without sand in continuous light at 200 lux show a clear-cut circadian rhythm with a period of less than $24 \mathrm{hr}$, with greatest activity at times of 'expected' dark. In contrast, amphipods provided with sand in which to burrow show no evidence of a circadian rhythm of emergence when kept at 200 lux, but they revert to a characteristic circadian rhythm of surface activity with a period of greater than $24 \mathrm{hr}$ if then transferred to continuous dim light. A further example of the difficulties which may be encountered in interpreting rhythms recorded under laboratory conditions is that groups of $T$. saltator show a free-running rhythm with a shorter mean period than the average period for animals kept singly in actographs (BrEgAzZI \& NAYLOR 1972). In groups of $T$. saltator it appears that overall timing of activity is to some extent synchronized by those animals which first become active, presumably those with the short- 
est period of rhythmicity. Evidently 'mutual entrainment' is another factor which it may be necessary to take into account when considering the ecological role of rhythmicity of some organisms.

The studies on $T$. saltator, a species which can be readily observed in the field, led us to consider the importance of in situ observations when designing experiments and interpreting experimental data on spontaneous rhythmicity. We have, therefore, taken this approach when carrying out the experiments reported here on two sublittoral, burrowing decapods Goneplax rhomboides (L.) and Nepbrops norvegicus (L.) and on the littoral species $U c a$ pugilator (Bosc).

\section{RESULTS}

\section{Rhythmicity in Goneplax rbomboides and Nepbrops norvegicus}

In first attempts to record rhythmic locomotor activity in Goneplax rhomboides the crabs were maintained in rectangular boxes and only occasionally were animals found to exhibit a circadian rhythm. Figure 1 illustrates the average hourly activity of 7 crabs recorded in continuous dim light and at constant temperature, and there was

a
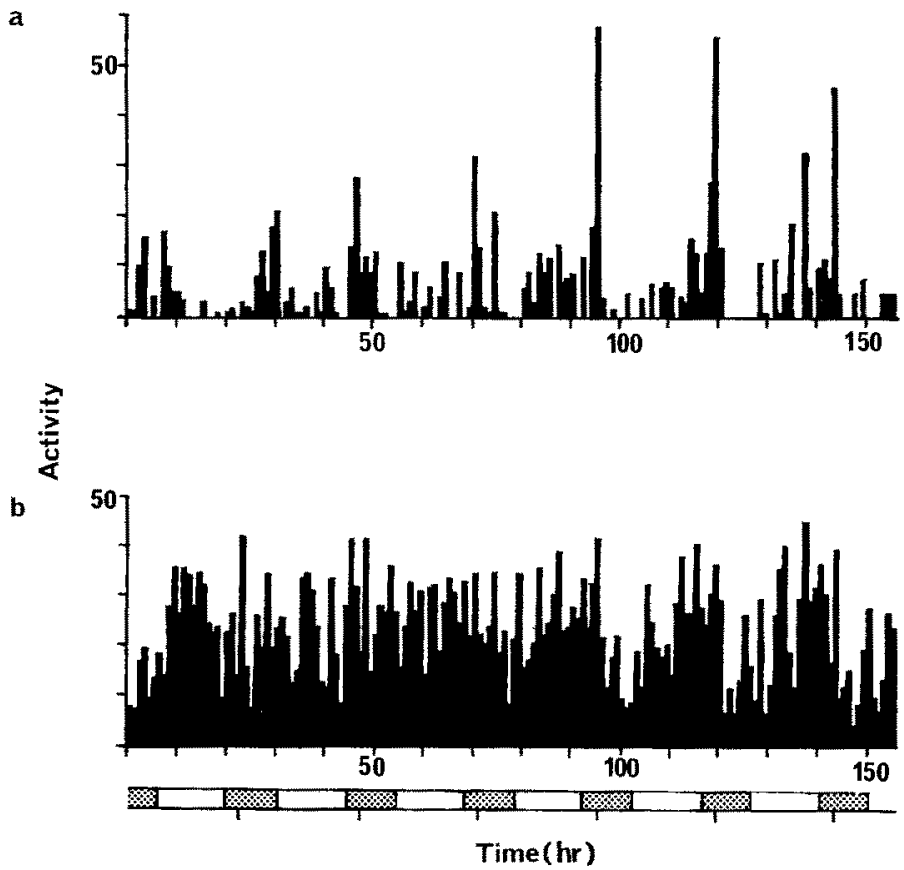

Fig. 1: Hourly activity values of freshly collected Goneplax rbomboides recorded in rectangular actographs in constant conditions; (a) one crab, $(b) 6$ crabs. (White bars indicate "expected" light periods; stippled bars indicate "expected" dark) 


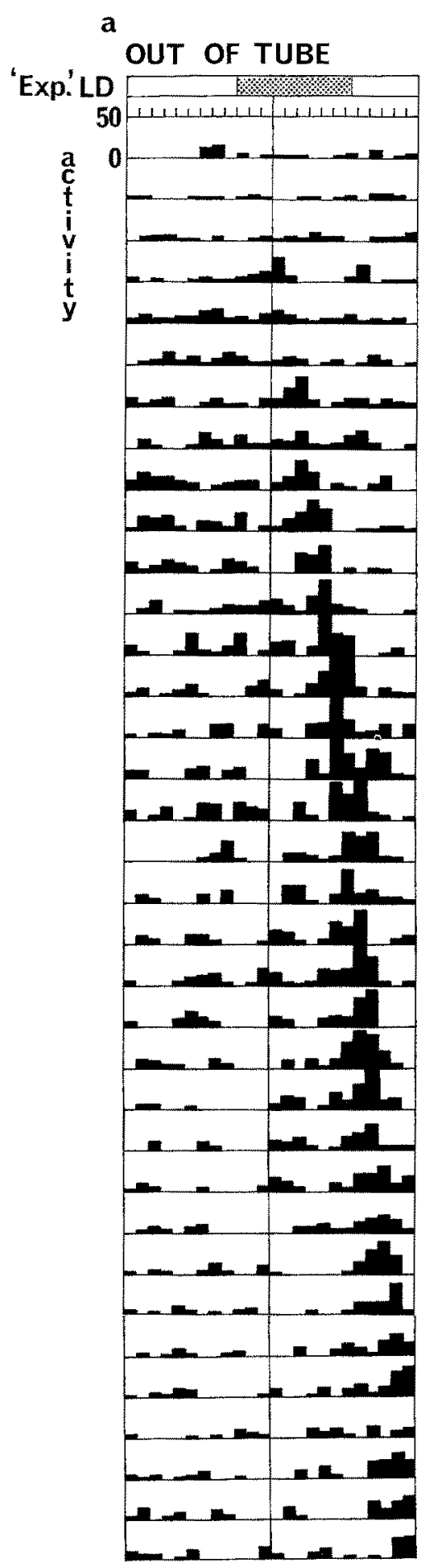

b

IN TUBE

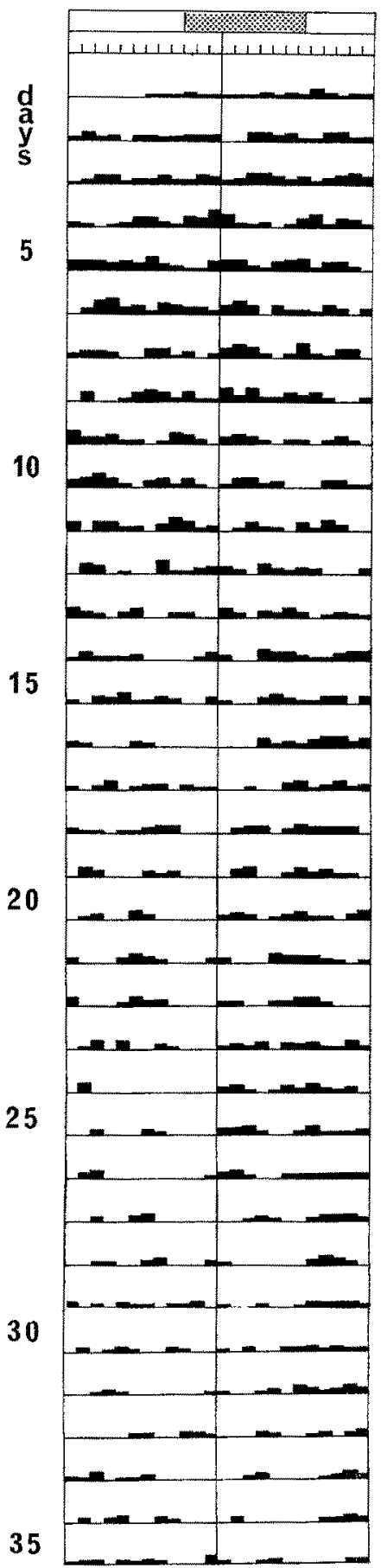


little evidence of rhythmicity except in one specimen which showed some indication of a circadian rhythm with greatest activity at 'expected' night. Following these preliminary experiments, new actographs were constructed based upon information derived from field studies. In these, one of us (R.J.A.A.) has investigated by diving the spatial distribution of burrows of $G$. rbomboides and has made burrow casts by injecting resin

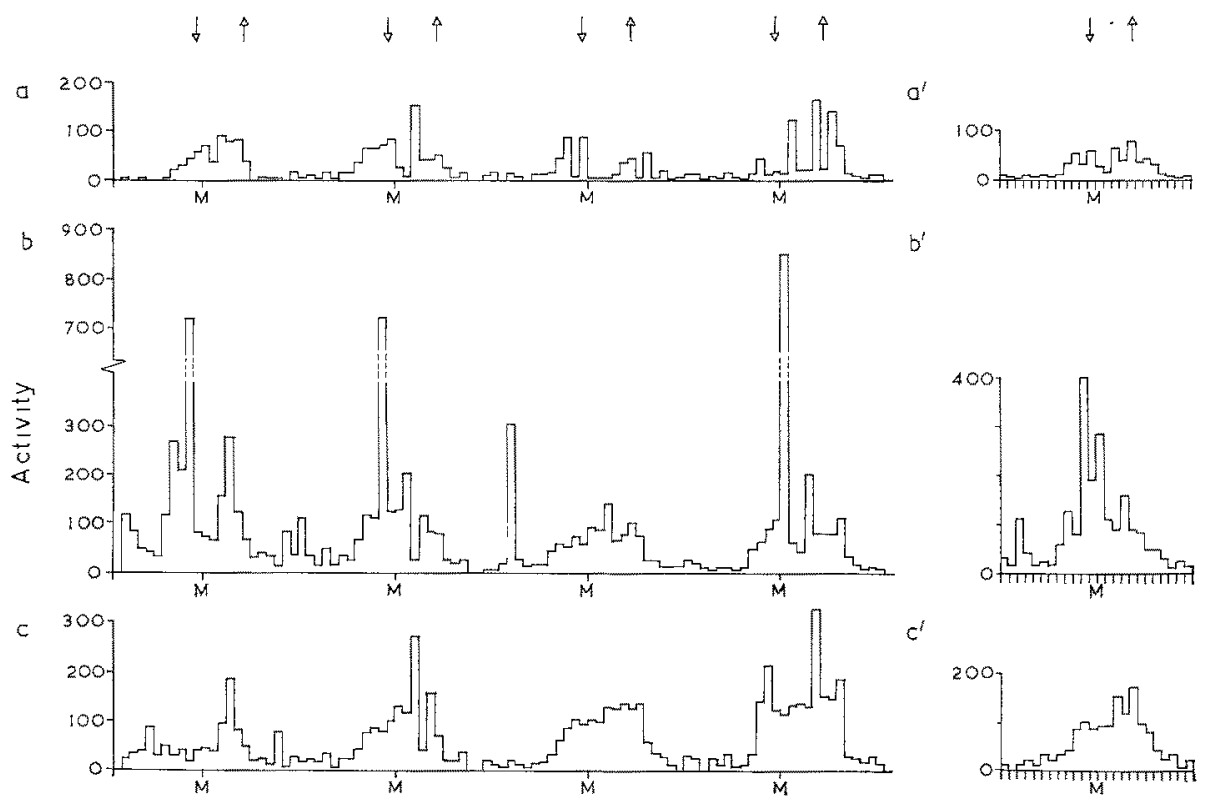

Fig. 3: Hourly activity values of freshly collected Nephrops norvegicus provided with an artificial burrow and maintained in constant conditions; (a) out of 'burrow' activity, $(b)$ activity at mouth of 'burrow', (c) activity within the 'burrow'. $a$ ', $b$ ', c', represent activity over an average 24 hr period (Arrows indicate times of dusk and dawn)

in situ. This study, together with similar work recently reported by RICE \& CHAPMAN (1971) led us to suppose that rhythmicity might be studied better in G. rbomboides by providing the crabs with artificial burrows. Actographs were therefore constructed using a blackened perspex tube $4.1 \mathrm{~cm}$ diameter and $30 \mathrm{~cm}$ in length, opening into two perspex end chambers measuring $15 \mathrm{~cm} \times 15 \mathrm{~cm} \times 15 \mathrm{~cm}$. The apparatus was filled with running sea water and dim red light beams were arranged to cross each end chamber and the central tube to impinge on three ORP 12 photosensitive resistors. Interruptions of the three light beams were monitored on 'Rustrak' event recorders and hourly activity values were then plotted. Specimens of $G$, rhomboides introduced into such actographs quickly entered the tube and appeared to use it as a normal burrow.

Fig. 2: Hourly activity values of freshly collected Goneplax rbomboides provided with an artificial burrow and maintained for 35 days in constant conditions; (a) out of tube activity, (b) in tube activity. (Shaded bar indicates time of "expected" darkness) 
Activity records of animals kept in continuous dim light in these actographs very consistently showed distinct circadian thythmicity in the pattern of exploration of the end chambers, activity within the 'burrow' often remaining high and more or less arhythmic. Figure 2 illustrates a typical result in which the period of the exploratory rhythm is slightly greater than $24 \mathrm{hr}$. A few animals expressed rhythmicity of periods more or less equal to or less than $24 \mathrm{hr}$ and the striking feature of many records was the extreme persistence of the rhythm in continuous dim illumination. In Figure 2 the rhythm remains clear-cut for 35 days, and thus resembles the high degree of persistence demonstrated for up to 42 days in the burrowing amphipod Talitrus saltator (BREGAZZI \& NAYLOR 1972).

Artificial burrows of the kind described above have also been used in experiments with Nepbrops norvegicus. This is a species which characteristically burrows in offshore muds, but which has recently been studied in situ in a shallow inshore locality by Chapman \& Rice (1971). A study of the behavioural rhythmicity of $N$. norvegicus is of particular interest in view of the commercial importance of this prawn for which there are known to be variations in commercial catches dependent upon the time of day. Freshly collected $N$. norvegicus show some variability in their daily pattern of activity in constant conditions, dependent upon age, sex and mode of capture, but some show clear-cut and persistent circadian rhythmicity (Fig. 3). In the actographs used for $N$. norvegicus activity is recorded in the 'burrow', at each entrance of the tube, and in each end chamber. The female recorded in the experiment illustrated in Figure 3 showed marked circadian rhythmicity at each location monitored, including the 'burrow'. Particularly striking is the very pronounced exploratory behaviour at the entrances of the tube at the beginning of some of the nocturnal peaks of activity out of the tube. Underwater observations (CHAPMAN \& RICE 1971) have shown that $N$. norvegicus is often seen at the burrow entrance prior to the period of emergence and the present result suggests that such positioning behaviour may be spontaneously rhythmic. There is also some evidence of bimodality in the activity peaks and it is tempting to consider this in relation to the known two peaks of abundance of $N$. norvegicus in commercial catches in the Irish Sea sampling area. However, not all animals show such bimodal spontaneous rhythms and in any event the peaks of commercial catches tend to be in the morning and afternoon. Further investigation is required of the relationship between the apparently nocturnal endogenous activity and the daytime peaks of abundance in commercial catches.

\section{Rhythmicity in Uca pugilator}

Very persistent rhythms of tidal and circadian periodicity have been reported for various physiological functions in Uca (Brown et al. 1954, BENNETT et al. 1957, BARNWeLL 1963) but the persistence of some of these rhythms has been questioned, largely on statistical grounds (Cole 1957, Enright 1965). More recently, Barnweli (1966) has confirmed the persistence of rhythmicity in single specimens of several species of this genus, and present results also confirm a persistent tidal rhythm in $U$. pugilator. In view of earlier work on the amphipod Talitrus saltator which appears to show 


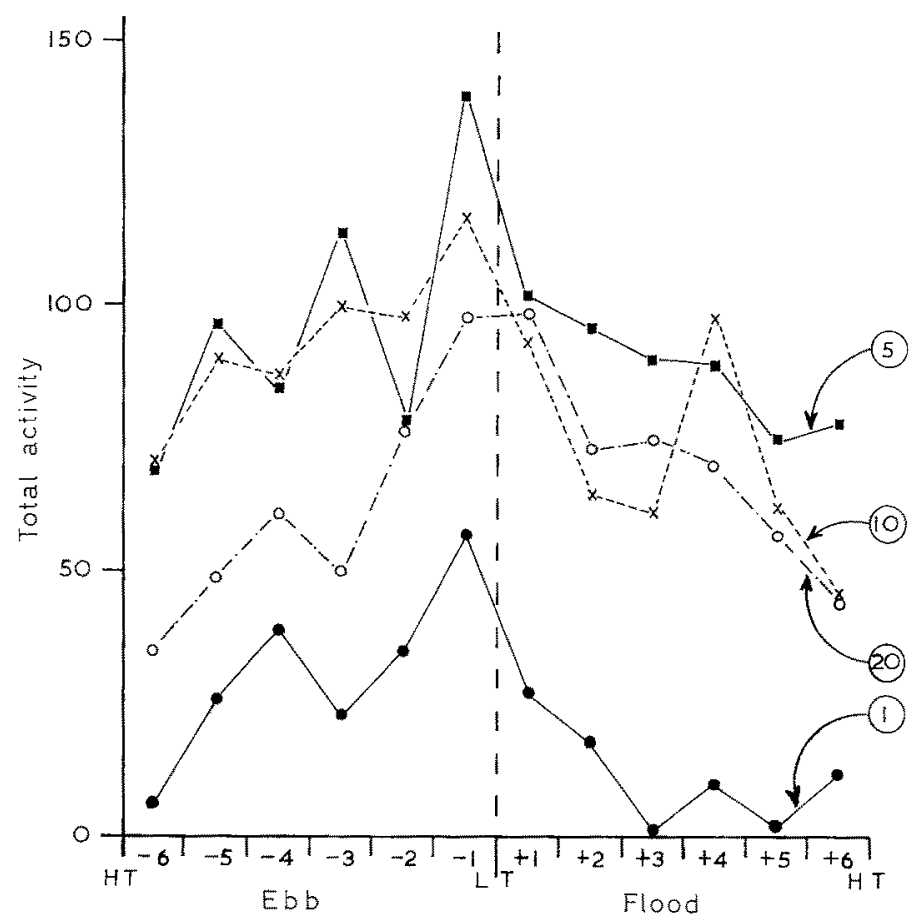

Fig. 4: Total hourly activity values of $1,5,10$ and 20 specimens of Uca pugilator recorded for 17 tidal cycles in constant conditions. Results are summated for each hour of a standard 12-hour tidal cycle centred on the time of low tide (LT)

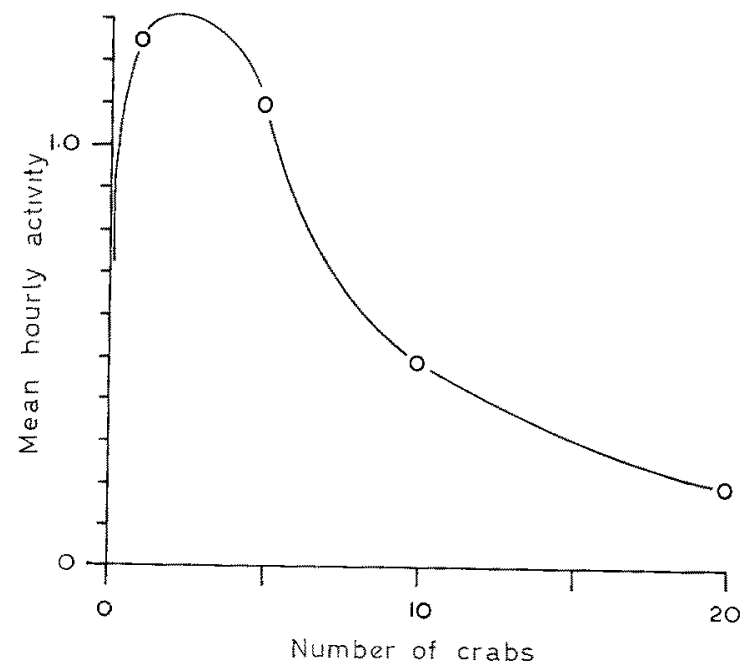

Fig. 5: Mean hourly activity of Uca pugilator kept in constant conditions and at different densities in actographs 
mutual entrainment of rhythmicity between animals (Bregazzr \& Naylor 1972), it seemed worthwhile to study this phenomenon in $U$. pugilator for which social interactions have been particularly well studied (Crane 1958, SALMON 1967). Also in view of present results on sublittoral burrowing decapods it seemed worthwhile to attempt some re-assessment of the nature of persistent rhythmicity in $U$. pugilator.

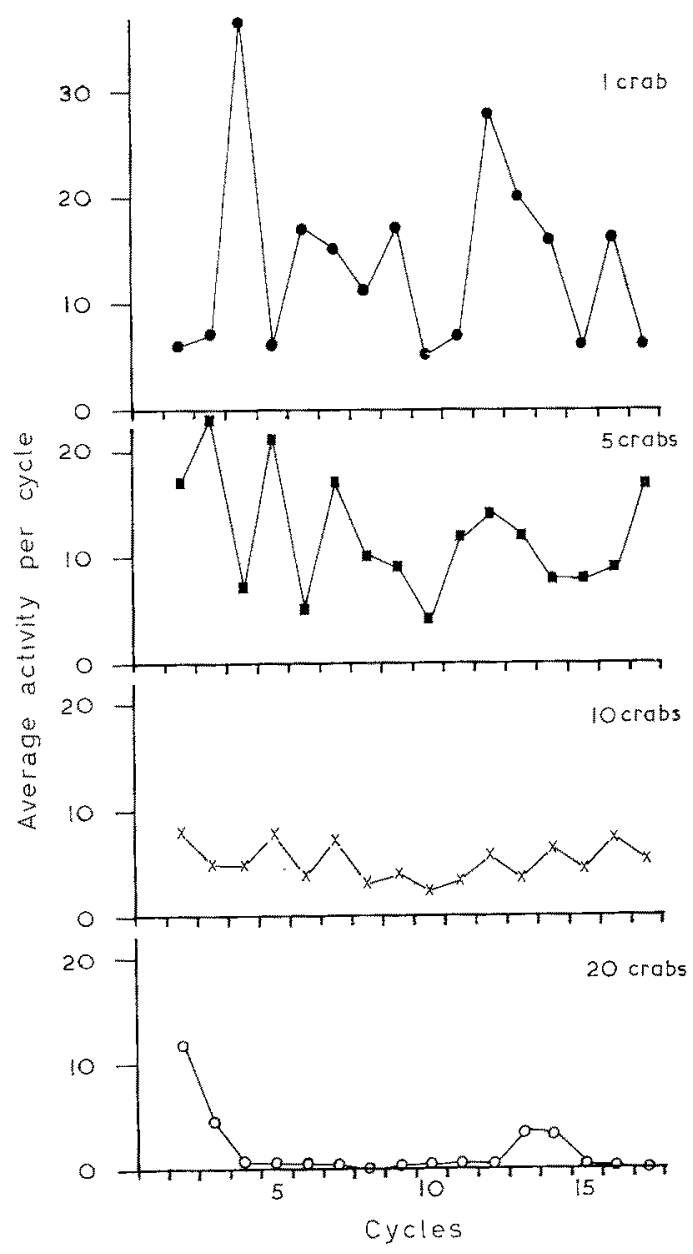

Fig. 6: Average activity per cycle in Uca pugilator run for 17 cycles in constant conditions with $1,5,10$ and 20 crabs in the actographs

In these experiments, specimens of $U$. pugilator were maintained in rectangular tanks $17.5 \times 27.5 \times 17.5 \mathrm{~cm}$ with dim red light beams shining across the floor and impinging on photoresistors, and hourly locomotor activity was recorded continuously in crabs kept at different densities. These results confirm the presence of a tidal rhythm of activity with a peak before 'expected' low tide. Evidence of rhythmicity persisted 
over about 10 days of the experiment and $12 \mathrm{hr}$ form-estimates, presenting total hourly activity values over a typical tidal cycle, are plotted for $1,5,10$ and $20 \mathrm{crabs}$ in Figure 4. There was no evidence of differences in the phase of the rhythm in crabs at different densities but it was particularly striking that total activity was not proportional to the numbers of crabs used. By plotting overall mean hourly activity against density (Fig. 5), it seems that the optimum number of crabs is very small for an actograph arena of the size used. A similar inhibition of activity at high densities was seen in T. saltator (BREGAZZI \& NAYLOR 1972), indicating that social interactions may inhibit activity in some species and this should be taken into account when designing actographs. In $U$. pugilator the average activity per cycle varies about a fairly constant level throughout the 17 cycles of the experiments (Fig. 6). There is greater variance at low densities but this result suggests that mutual interactions between the crabs are quickly established in the actographs.

\section{CONCLUSIONS}

Present studies and those of BREgAzzI \& NAYLOR (1972) indicate that burrowing crustaceans behave differently in the expression of so-called 'spontaneous' rhythmicity, dependent upon the nature of the actograph and the possible interaction of experimental animals. In situ studies are clearly important before designing actographs and before attempting to assess the adaptive significance of behaviour patterns recorded in the laboratory.

A striking feature of the results obtained with Talitrus saltator (BREGAZZI \& NAYLOR 1972) and in present work, is the extreme persistence of rhythmicity in burrowing crustaceans, particularly when provided with a substrate in which to burrow or with a simulated burrow. Rhythmicity in non-burrowing forms tends to be much less persistent, the tidal rhythm of Carcinus maenas being lost after 4-5 days in constant conditions (NAYLoR 1958). It seems unlikely that the artificial nature of the actographs affected the persistence of the rhythm in C. meanas and it is noteworthy that the rhythm of $U c a$ pugilator persists for longer than that of $C$. maenas in similar actographs (BENNETT et al. 1957, BARNwell 1966). Brown $(1958,1965)$ has regarded persistence in so-called constant conditions as a basis for supporting the view that rhythmicity may be controlled by subtle environmental factors and hence less dependent upon internal physiological 'clocks' than many other workers have supposed. There has been criticism of this interpretation of some of the fiddler crab results (CoLE 1957, ENRIGHT 1965) but there seems little doubt from present work and work by BARNWELL (1966) that locomotor rhythmicity is persistent in $U c a$ pugilator though less cleary so than in Talitrus saltator (BREGAzZI \& NAYLOR 1972) and Goneplax rbomboides.

In view of the nature of rhythmicity in these burrowing forms it is worthwhile considering the possibility that highly persistent endogenous rhythmicity is an adaptive feature of burrowing crustaceans which emerge to forage freely on the substratum during the active period. Elsewhere it has been suggested (RoDriguez \& NAYLOR 1972) that the degree of endogeneity of a biological rhythm may be least in surface-living 
sessile organisms which are structurally well adapted to withstand a wide range of environmental variables, and greatest in mobile but cryptic animals for which behavioural anticipation of environmental change would be advantageous. This argument can be extended to burrowing species in which it would be of considerable selective advantage to have a pronounced endogenous component in their behavioural rhythms. This would enable them to return to their burrow or, in the case of $T$. saltator to a preferred narrow zone on the shore, in advance of the onset of unfavourable conditions. Equally, the endogenous 'clock' would assist in restricting activity to particular times of day or permit animals to remain burrowed for one or more cycles without constant reference to environmental variables on the surface. They would thus conserve energy which is probably a basic physiological advantage gained in the evolution of a biological rhythm (BREGAZZI \& NAYLOR 1972). It may be for these reasons that rhythmicity is so persistent in burrowing decapods, the persistence being adaptive and not necessarily implying that control is mediated by residual external variables as suggested by Brown (1958).

\section{SUMMARY}

1. Emphasis is placed upon the need for in situ observations on marine animals when designing actographs for laboratory recording of locomotor rhythmicity and when interpreting the adaptive value of such rhythmicity.

2. Two burrowing decapods, Goneplax rhomboides and Nepbrops norvegicus, show highly persistent circadian rhythms when kept in actographs incorporating simulated burrows.

3. In some other crustaceans interactions between individuals affect the period and amplitude of the spontaneous locomotor rhythm.

4. The significance of very persistent rhythms in burrowing species is discussed.

Acknowledgements. These studies began with financial support from the Science Research Council and are continuing with a research grant from the Natural Environment Research Council. We are grateful to Professor E. W. KNIGHT-Jones for facilities at the University College of Swansea, and one of us (EN) is grateful to Dr. J. D. CostLow, Jr. for facilities at the Duke University Marine Laboratory, Beaufort, N. Carolina, where the experiments on Uca pugilator were carried out. We also thank Mr. H. BALEY for technical help.

\section{LITERATURE CITED}

BarnwelL, F., 1963. Observations on daily and tidal rhythms in some fiddler crabs from equatorial Brazil. Biol. Bull. mar. biol. Lab., Woods Hole 125, 399-415.

- 1966. Daily and tidal patterns of activity in individual fiddler crabs (genus $U c a$ ) from the Woods Hole region. Biol. Bull. mar. biol. Lab., Woods Hole 130, 1-17.

Bennet', M. F., Shriner, J. \& Brown, R. A., 1957. Persistent tidal cycles of spontaneous motor activity in the fiddler crab, Uca pugnax. Biol. Bull. mar. biol. Lab., Woods Hole $112,267-275$.

Bregazzr, P. K. \& Naylor, E., 1972. The locomotor activity rhythm of Talitrus saltator Montagu) (Crustacea: Amphipoda). J. exp. Biol. 57, 375-391. 
Brown, F. A. Jr., 1958. Studies in the timing mechanisms of daily, tidal and lunar periodicities in organisms. In: Perspectives in marine biology. Ed. by A. A. Buzzatr-Traverso. Univ. of Calif. Press. Berkeley, Calif. 269-282.

- 1965. A unified theory for biological rhythms: rhythmic duplicity and genesis of "circa" periodisms. In: Circadian clocks. Ed. by J. Ascroff. North-Holland Publ., Amsterdam, 231-261.

- Bennett, M. F. \& WeBb, H. M., 1954. Persistent daily and tidal rhythms of $\mathrm{O}_{2}$-consumption in fiddler crabs. J. cell. comp. Physiol, 44, 477-506.

Chapman, C. J. \& Rice, A. L., 1971. Some direct observations on the ecology and behaviour of the Norway lobster Nephrops norvegicus. Mar. Biol. 10, 321-329.

CoLE, L. C., 1957. Biological clock in the unicorn. Science, N.Y. 125, 874.

Crane, J., 1958. Aspects of social behaviour in fiddler crabs, with special reference to Uca maracoani (LATrerLle). Zoologica, N.Y. 43, 113-130.

Enright, J. T., 1965. The search for rhythmicity in biological time-series. J. theor. Biol. 8, 426-468.

NAYLoR, E., 1958. Spontaneous tidal and diurnal rhythms of locomotory activity in Carcinus maenas (L.). J. exp. Biol. 35, 602-610.

Rice, A. L. \& Chapman, C. J., 1971. Observations on the burrows and burrowing behaviour of two mud-dwelling decapod crustaceans, Nephrops norvegicus and Goneplax rhomboides. Mar. Biol. 10, 330-342.

Rodriguez, G. \& NAYLOR, E., 1972. Behavioural rhythms in littoral prawns. J. mar. biol. Ass. U.K. 52, 81-95.

Salmon, M., 1967. Coastal distribution, display and sound production by Florida fiddler crabs (genus $U c a$ ). Anim. Behav. 15, 449-459.

First author's address: Dr. R. J. A. Atrnnson

Marine Biological Station

University of Liverpool

Port Erin

Isle of Man

United Kingdom 